\title{
Marine Algae of French Frigate Shoals, Northwestern Hawaiian Islands: Species List and Biogeographic Comparisons ${ }^{1}$
}

\author{
Peter S. Vroom, ${ }^{2}$ Kimberly N. Page, ${ }^{2,3}$ Kimberly A. Peyton, ${ }^{3}$ and 7. Kanekoa Kukea-Shultz ${ }^{3}$
}

\begin{abstract}
French Frigate Shoals represents a relatively unpolluted tropical $\mathrm{Pa}-$ cific atoll system with algal assemblages minimally impacted by anthropogenic activities. This study qualitatively assessed algal assemblages at 57 sites, thereby increasing the number of algal species known from French Frigate Shoals by over $380 \%$ with 132 new records reported, four being species new to the Hawaiian Archipelago, Bryopsis indica, Gracilaria millardetii, Halimeda distorta, and an unidentified species of Laurencia. Cheney ratios reveal a truly tropical flora, despite the subtropical latitudes spanned by the atoll system. Multidimensional scaling showed that the flora of French Frigate Shoals exhibits strong similarities to that of the main Hawaiian Islands and has less commonality with that of most other Pacific island groups.
\end{abstract}

French Frigate Shoals, an atoll located close to the center of the 2,600-km-long Hawaiian Archipelago, is part of the federally protected Northwestern Hawaiian Islands Coral Reef Ecosystem Reserve. In stark contrast to the more densely populated main $\mathrm{Ha}-$ waiian Islands, the reefs within the ecosystem reserve continue to be dominated by top predators such as sharks and jacks (ulua) and serve as a refuge for numerous rare and endangered species no longer found in more degraded reef systems (Friedlander and De-

${ }^{1}$ This research was conducted under the Joint Institute for Marine and Atmospheric Research's Coastal Research Theme as part of a cooperative study of the Northwestern Hawaiian Islands Coral Reef Ecosystem. The study is funded and directed by the Coral Reef Ecosystem Division, Pacific Islands Fisheries Science Center, NOAA, Honolulu, Hawai'i. Funding to the Coral Reef Ecosystem Division for scientific expeditions to the Northwestern Hawaiian Islands was provided through the NOAA Fisheries Office of Habitat Conservation as part of the NOAA Coral Reef Conservation Program. Manuscript accepted 1 May 2005.

${ }^{2}$ Joint Institute for Marine and Atmospheric Research, University of Hawai'i, 1125B Ala Moana Boulevard, Honolulu, Hawai'i 96814 (phone: 808-592-2817; fax: 808-592-7013; e-mail: Peter.Vroom@noaa.gov).

${ }^{3}$ Department of Botany, University of Hawai'i at Mānoa, 3190 Maile Way, Honolulu, Hawai'i 96822.

Pacific Science (2006), vol. 60, no. 1:81-95

(C) 2006 by University of Hawai'i Press

All rights reserved
Martini 2002, Maragos and Gulko 2002). The National Oceanic and Atmospheric Administration (NOAA) Fisheries Coral Reef Ecosystem Division (CRED) and Northwestern Hawaiian Islands Reef Assessment and Monitoring Program (NOWRAMP) began conducting yearly assessment and monitoring of subtropical reef ecosystems at French Frigate Shoals in 2000 to better support the long-term conservation and protection of this relatively intact ecosystem and to gain a better understanding of natural biological and oceanographic processes in this area.

Despite past pioneering efforts to document macroalgal diversity in the Northwestern Hawaiian Islands (Buggeln 1965, Tsuda 1965, 1966, Balazs 1979, Abbott 1989), analyses have been hampered because of a paucity of algal data from these areas, the remoteness of islands being assessed, and the time-intensive techniques necessary to properly identify and catalog the numerous macroalgae, epiphytes, and turf algae encountered. In this study, algal communities from an unprecedented number of sites and a variety of habitats at French Frigate Shoals were sampled by divers in the field and analyzed at a level of taxonomic resolution rarely encountered in reef surveys from other regions of the world (Dodge et al. 1982, Rogers et al. 1983, Liddell and Ohlhorst 1987, Chiappone and Sullivan 1997, Chiappone et al. 1997, 2001, Diaz-Pulido and Diaz 1997, McField 
et al. 2001, Costa et al. 2002, Diaz-Pulido and Garzón-Ferreira 2002, Schils and Coppejans 2003). As a result of this work, two species of algae new to science and endemic to French Frigate Shoals have been described (Vroom and Abbott 2004a,b), and reproductive features of the green alga Halimeda velasquezii Taylor have been scientifically reported for the first time (Vroom and Smith 2003). In this paper we provide an updated comprehensive species list of algal specimens known from French Frigate Shoals and compare the marine flora of French Frigate Shoals with that of other Pacific islands.

\section{MATERIALS AND METHODS}

\section{Location}

Centered at approximately $23.45^{\circ} \mathrm{N}$ latitude and $166.11^{\circ} \mathrm{W}$ longitude (Figure 1), French Frigate Shoals represents a large, open atoll containing numerous low sand islets and two basalt pinnacles. The eastern side of the atoll system consists of an ocean-facing reef system with classic reef slope, reef crest, and backreef regions. Inner lagoonal areas are characterized by shallow sandy and hard bottom communities with numerous, sometimes extensive, patch and linear reefs. The submerged central portion of the atoll is the location of La Pérouse Pinnacles, the only emergent basaltic remnants of an ancient volcano (Miller et al. 2003). Although most of the atoll system is relatively unimpacted by human activities, Tern Island was extended for military purposes during World War II from a length of $550 \mathrm{~m}$ to $945 \mathrm{~m}$ using dredged coral reef material and currently is the site of a Hawaiian National Wildlife Refuge facility. East Island, about $8 \mathrm{~km}$ from Tern Island, had extensive military occupation during World War II and housed a U.S. Coast Guard Station from 1944 to 1952.

\section{Data Collection}

Research expeditions to French Frigate Shoals during July 1990 and late summer to early autumn 2000-2002 visited 57 diverse geographic areas and habitats for qualitative algal analyses (Appendix). At each site, algae were collected haphazardly from a 3-m-wide swath along two $25-\mathrm{m}$ transect lines set in a singlefile row, with each transect separated by $\sim 10 \mathrm{~m}$. With the exception of some shallower back-reef and lagoonal sites, most transects were placed at a standard $10-$ to $15-\mathrm{m}$ depth (Appendix).

\section{Data Analysis}

Immediately after collection in the field, samples were brought aboard a research vessel and frozen in sealable bags. After completion of each expedition, microscope slides and herbarium pressings were made of samples for species identification. Microscopic specimens were examined with a compound microscope (Nikon E400, Melville, New York) and photographed with a digital camera $\left(\mathrm{Ni}^{-}\right.$ kon CoolPix 995). All microscope slides and herbarium specimens are currently in the personal herbaria of Isabella Abbott (IA 27138IA 27556) and Peter Vroom (PSV 20000PSV 20010, PSV 20012-PSV 20015, PSV 20018-PSV 20096) and are slated for eventual deposition in the Bishop Museum, Honolulu, Hawai'i.

Recent taxonomic treatments of the marine flora of the Hawaiian Archipelago (Abbott 1999, Abbott and Huisman 2004) present original citations, basionyms, synonyms, and distribution for almost all algal species found at French Frigate Shoals. However, the nomenclature presented in this paper reflects current practice (Guiry and NicDhonncha 2005) and may differ slightly from those earlier treatments. For all new records, information is presented as to the source or the location of verifiable material, and original citations are provided together with information on the type locality, the basionym, and taxonomic synonyms.

To compare the marine benthic algal flora of French Frigate Shoals to that of other islands in the tropical Pacific, data on the presence and absence of species and genera were compiled from eight additional islands or archipelagoes whose marine floras have been recently reviewed (French Polynesia [Setchell 1926, Payri and N'Yeurt 1997, Payri et al. 


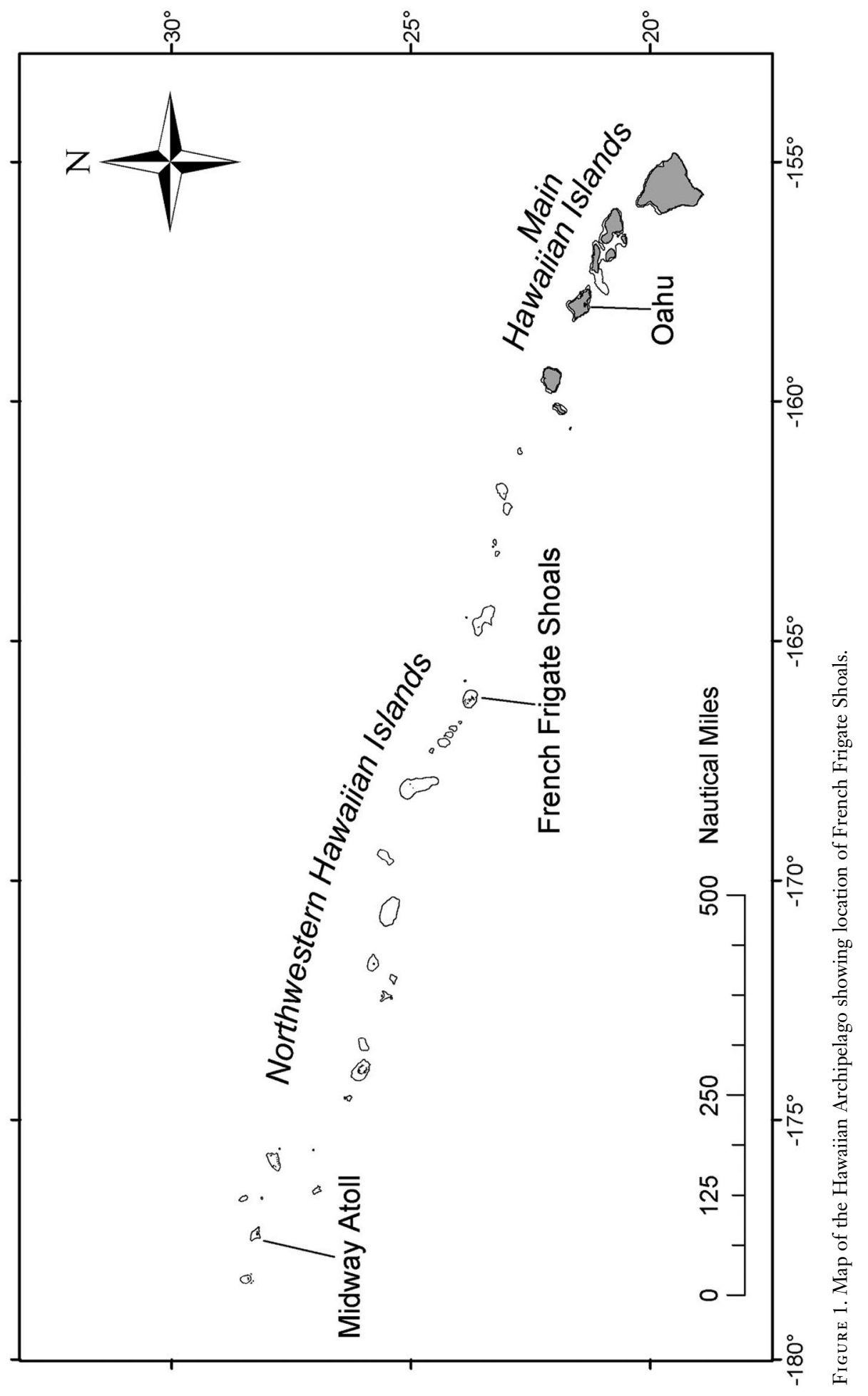


2000], Fiji [N'Yeurt et al. 1996, South and Skelton 2003], Palau Archipelago [Tsuda 2002a], Yap State [Tsuda 2002b], Marshall Islands [Tsuda 2002c], Guam and the Commonwealth of the Northern Mariana Islands [CNMI] [Lobban and Tsuda 2003, Tsuda 2003]; Pohnpei and Ant Atoll [Hodgson and McDermid 2000, McDermid et al. 2002], and the main Hawaiian Islands [Abbott 1999, Abbott and Huisman 2004]). Bray-Curtis similarity matrices of species and genus presence among islands were generated using PRIMER-E software (Clarke and Warwick 2001), and multidimensional scaling (number of restarts $=30$ ) was used to map relationships between islands based on floristic composition. Because the nongeniculate Corallinales of Hawai'i are currently under revision (Y. Chamberlain, pers. comm.), this group was excluded from our analysis for all islands. Ratios of red, green, and brown algae at French Frigate Shoals were compared using the Cheney ratio (no. of red + green algal species/no. of brown algal species [Cheney 1977]).

\section{RESULTS}

A total of 157 algal species was found during the 1990 and 2000-2002 expeditions to French Frigate Shoals (Table 1), with 74\% being new records for the atoll (Abbott 1989, 1999, Abbott and Huisman 2004). Approximately $47 \%$ were macroalgal species, and the rest were epiphytes or members of the turf community. No known alien algae were documented, and native species with known invasive qualities (e.g., Caulerpa taxifolia (Vahl) C. Agardh [Meinesz 1999, Vroom and Smith 2001]) did not exhibit invasive tendencies. Four species new to the Hawaiian Archipelago (Bryopsis indica Gepp \& Gepp, Gracilaria millardetii (Montagne) J. Agardh, Halimeda distorta (Yamada) Hillis-Colinvaux, and an unidentified species of Laurencia) were reported (Table 2, Figure 2), along with two species new to science, Acrosymphyton brainardii Vroom \& Abbott 2004a and Scinaia buismanii Vroom \& Abbott 2004b. Twenty-two species found during previous assessments of the atoll (Tsuda 1966, Hollenberg 1968,
Brostoff 1984, Abbott 1989, 1999, Abbott and Huisman 2004) were not collected (Table 1).

Of the 179 algal species known from French Frigate Shoals, 118 are red algal species representing 59 genera, 42 are green algal species from 22 genera, and 19 are brown algal species in 14 genera (Table 3). Cheney ratios of 8.4 and 5.8 for species and genus comparisons, respectively, revealed a tropical flora without temperate influence (Cheney 1977). A multidimensional scaling ordination of Pacific islands based on marine macroalgal floras by species revealed that South Pacific locales (French Polynesia and Fiji) and Micronesian islands (Yap, Palau, Guam and CNMI, and the Marshall Islands) form distinct clusters (Figure 3). Although the Hawaiian Islands (French Frigate Shoals and the main Hawaiian Islands) were clearly distinct from these clusters (Figure 3), the placement of Pohnpei and Ant Atoll suggests that the marine flora of these islands has affinities to those of both its Micronesian neighbors and Hawai'i. A similar analysis using only genera (data not shown) failed to group islands into distinct clusters.

\section{DISCUSSION}

This study increased the number of algal species known from French Frigate Shoals from 47 (Abbott 1989, 1999, Abbott and Huisman 2004) to 179 , an increase of over $380 \%$ (Table 1). A Cheney ratio of 8.4 is well above the "tropical threshold" of 6.0 (Cheney 1977, Schils and Coppejans 2003) and indicates that the marine flora of French Frigate Shoals represents a tropical ecosystem with minimal temperate influences. Red algal species outnumbered green and brown algal species 2.8 and 6.2 times, respectively. In addition, the geographic isolation of French Frigate Shoals combined with the numerous types of benthic habitat formed by geologic processes and varying exposure to oceanographic forces permitted an evolutionarily diverse assemblage of algal species that is unique from that of other Pacific islands (Figure 3).

Many algal species from Hawaici have well-established Indo-Western Pacific distri- 
TABLE 1

Species Inventory of Marine Algae Collected at French Frigate Shoals, Northwestern Hawaiian Islands

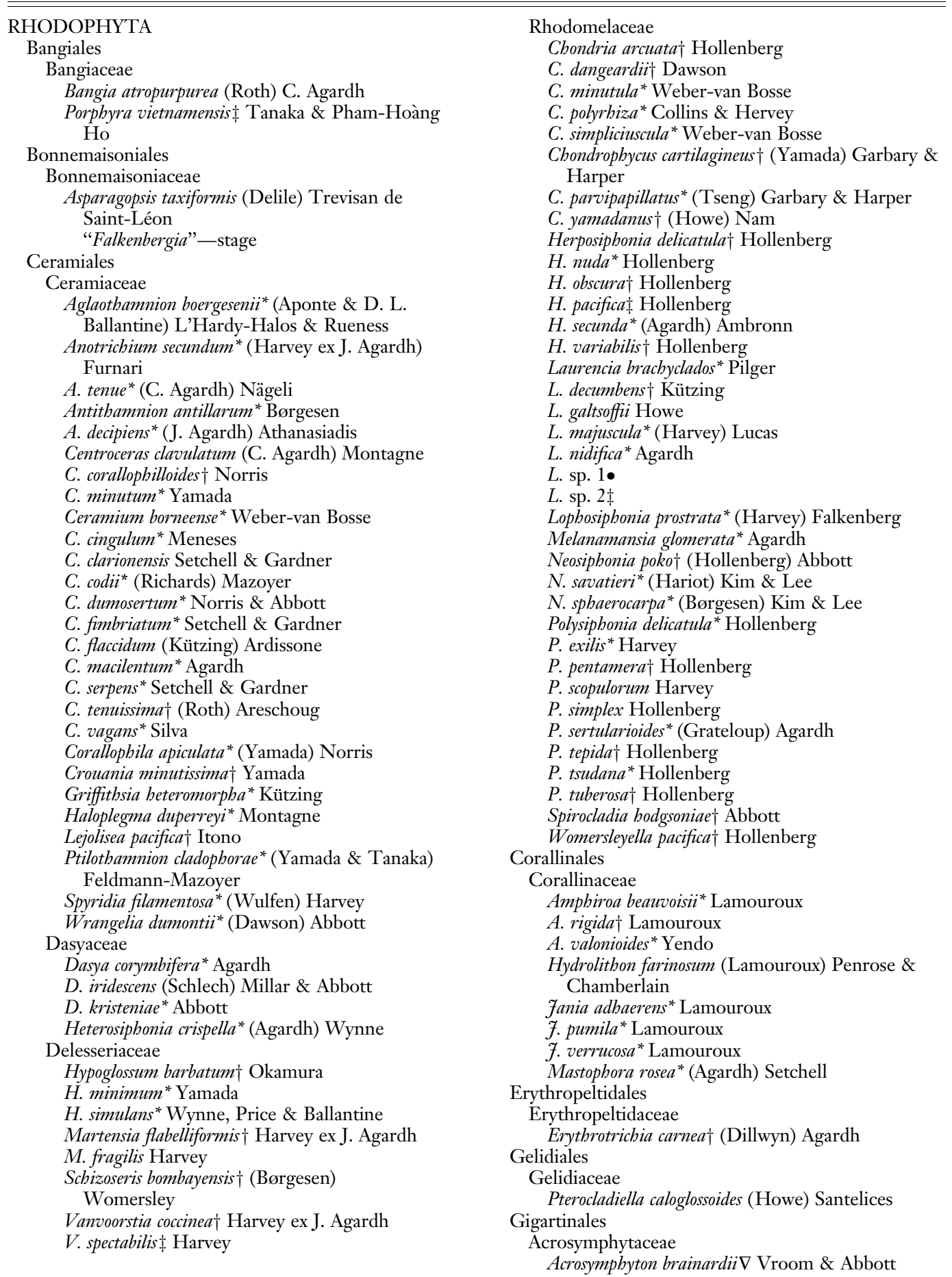


TABLE 1 (continued)

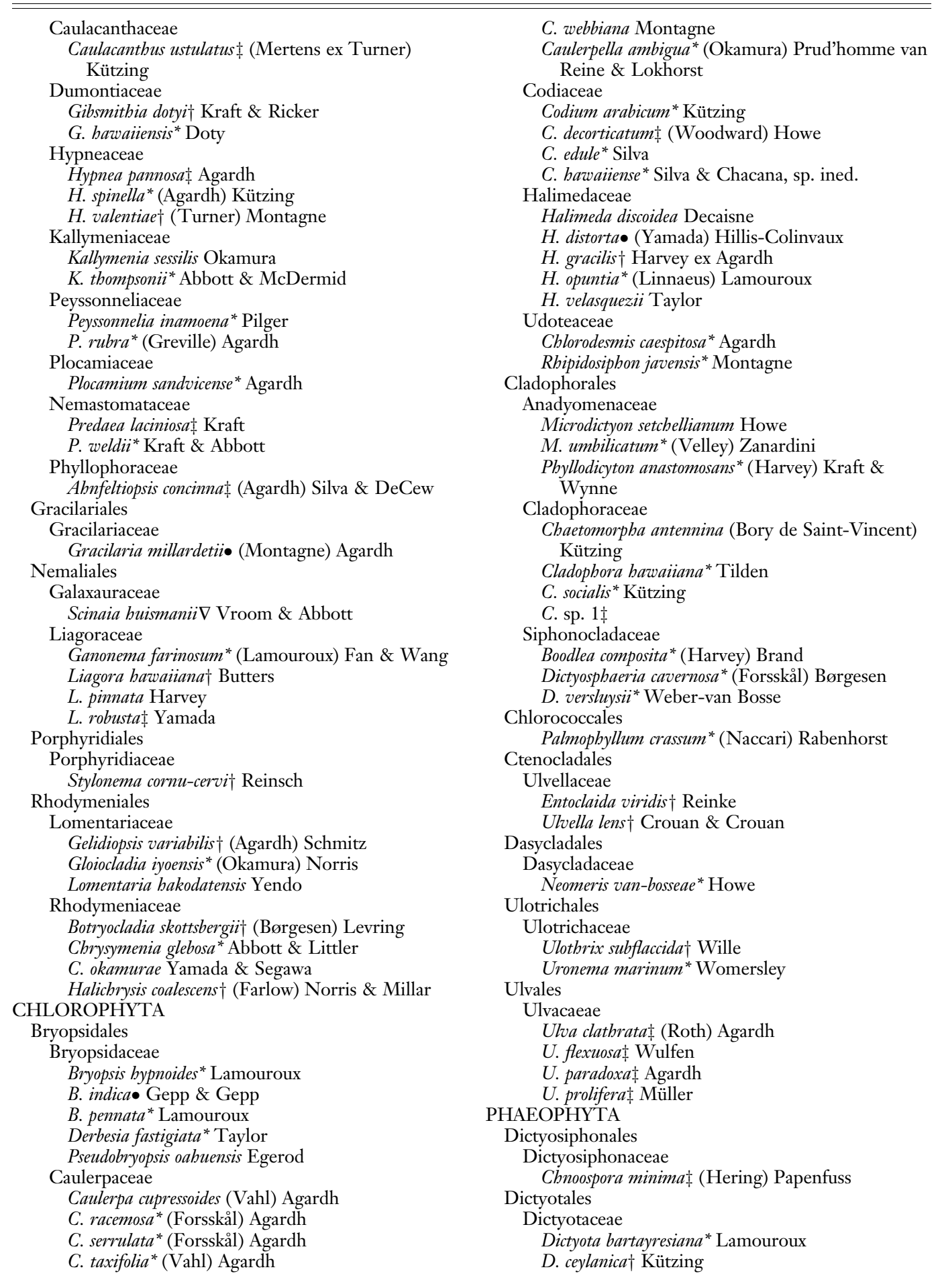


TABLE 1 (continued)

\begin{tabular}{|c|c|}
\hline $\begin{array}{l}\text { D. stolonifera } \ddagger \text { Dawson } \\
\text { Distromium flabellatum* Womersley } \\
\text { Lobophora variegata* (Lamouroux) Womersley ex } \\
\text { Oliveira } \\
\text { Padina sanctae-crucis* Børgesen } \\
\text { "Vaughaniella"--stage } \\
\text { Stypopodium flabelliforme* Weber-van Bosse } \\
\text { Ectocarpales } \\
\text { Ectocarpaceae } \\
\text { Asteronema breviarticulatum (Agardh) Ouriques \& } \\
\text { Bouzon } \\
\text { Feldmannia irregularis } \ddagger \text { (Kützing) Hamel } \\
\text { Hincksia mitchelliae } \text { Silva } \\
\text { Sacales } \\
\text { Sargarsaceae }\end{array}$ & $\begin{array}{l}\text { S. polyphyllum* Agardh } \\
\text { Turbinaria ornata (Turner) Agardh } \\
\text { Scytosiphonales } \\
\text { Scytosiphonaceae } \\
\text { Hydroclatbrus clatbratus } \ddagger \text { (Agardh) Howe } \\
\text { Sphacelariales } \\
\text { Sphacelariaceae } \\
\text { Sphacelaria novae-hollandiae } \ddagger \text { Sonder } \\
\text { S. rigidula* Kützing } \\
\text { S. tribuloides* Meneghini } \\
\text { Sporochnales } \\
\text { Sporochnaceae } \\
\text { Sporochnus dotyi } \ddagger \text { Brostoff }\end{array}$ \\
\hline
\end{tabular}

Note: Validity of species and authors ascertained through AlgaeBase (Guiry and NicDhonncha 2005). *, new record for French Frigate Shoals; $\dagger$, new record for the Northwestern Hawaiian Islands; $\bullet$, new record for the Hawaiian Archipelago; $\nabla$, endemic to French Frigate Shoals; $\ddagger$, reported in Tsuda (1966), Hollenberg (1968), Brostoff (1984), or Abbott (1989), but not collected during 1990 or 2000-2002 expeditions.

TABLE 2

Taxonomic and Distributional Information for Three Species New to the Hawaiian Archipelago

\begin{abstract}
Division Chlorophyta, Order Bryopsidales, Family Bryopsidaceae, Genus Bryopsis Lamouroux
Bryopsis indica Gepp \& Gepp, 1908:169-170, pl. 22: figs. 10, 11

World distribution: East South America: Brazil (Joly 1957); East Africa, Indian Subcontinent, and Indian Ocean:

Bangladesh (Silva et al. 1996), India (Silva et al. 1996, Sahoo et al. 2001), Sri Lanka (Silva et al. 1996), Chagos

Archipelago (Silva et al. 1996), Maldives (Silva et al. 1996), Somalia (Silva et al. 1996), Kenya (Silva et al. 1996),

Tanzania (Coppejans et al. 2000), Seychelles (Silva et al. 1996), Mauritius (Børgesen 1940, Silva et al. 1996); East

Asia: Japan (Yoshida et al. 1990, Yoshida 1998); Southeast Asia: Vietnam (Pham-Hoàng 1969), Singapore (Teo and

Wee 1983, Silva et al. 1996), Philippines (Silva et al. 1987); Pacific Islands: Solomon Islands (Womersley and Bailey

1970); Australia and New Zealand: Queensland (Cribb 1996; Phillips 1997, 2002), Lord Howe Island (Kraft 2000),

Papua New Guinea (Coppejans et al. 2001)
\end{abstract}

Division Chlorophyta, Order Bryopsidales, Family Halimedaceae, Genus Halimeda Lamouroux

Halimeda distorta (Yamada) Hillis-Colinvaux, 1968:33, figs. 4, 6:2

Basionym: Halimeda incrassata f. distorta Yamada, 1941:119, fig. 14

Synonym: Halimeda incrassata f. distorta Yamada, 1941:119, fig. 14

World distribution: East Africa, Indian Subcontinent, and Indian Ocean: Kenya (Coppejans et al. 2000), Tanzania

(Coppejans et al. 2000); East Asia: Japan (Yoshida 1998); Southeast Asia: Indonesia (Verheij and Prud'homme van

Reine 1993); Pacific Islands: French Polynesia (Payri et al. 2000); Australia and New Zealand: Papua New Guinea

(Coppejans et al. 2001)

Division Rhodophyta, Order Gracilariales, Family Gracilariaceae, Genus Gracilaria Greville

Gracilaria millardetii (Montagne) J. Agardh, 1885:64 (forma millardetii)

Basionym: Rhodymenia millardetii Montagne in Montagne and Millardet, 1862:9-10, pl. XXV: fig. 3

Synonym: Rhodymenia millardetii Montagne in Montagne and Millardet, 1862:9-10, pl. XXV: fig. 3

World distribution: East Africa, Indian Subcontinent, and Indian Ocean: Andaman Islands (Silva et al. 1996), India (Silva et al. 1996, Sahoo et al. 2001), Yemen (Silva et al. 1996), Kenya (Silva et al. 1996), Tanzania (Silva et al. 1996), Mozambique (Silva et al. 1996), South Africa (Silva et al. 1996), Madagascar (Silva et al. 1996), Seychelles (Silva et al. 1996), Mauritius (Børgesen 1943, Silva et al. 1996), Réunion (Silva et al. 1996)

Note: Information from AlgaeBase (Guiry and NicDhonncha 2005). 


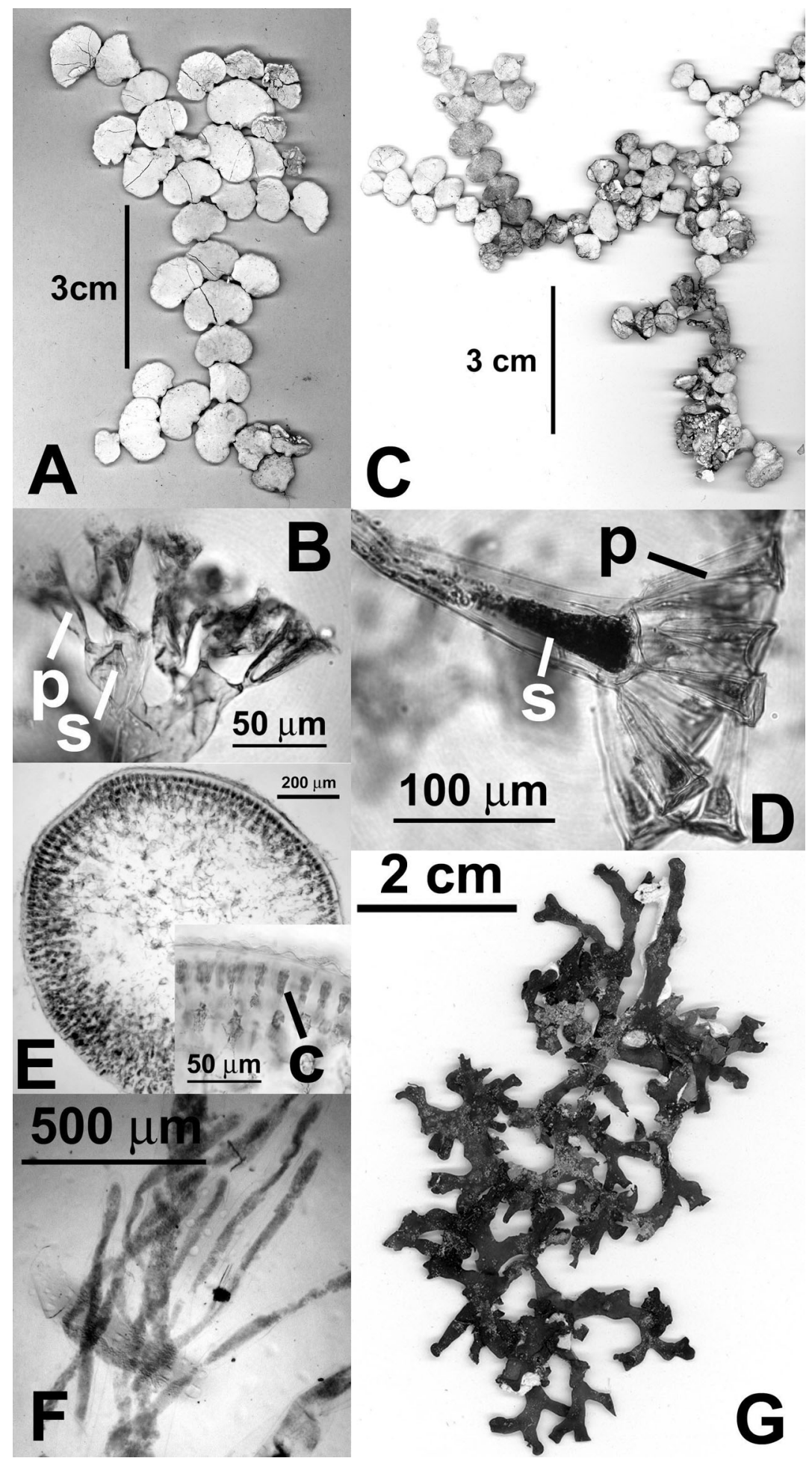


butions (Abbott 1999). Therefore it is not surprising that two species new to the Hawaiian Archipelago reported from French Frigate Shoals, Bryopsis indica (Figure $2 F$ ) and Halimeda distorta (Table 2, Figure 2A,B), also exhibit Indo-Pacific distributional patterns (Guiry and NicDhonncha 2005). Before its discovery at French Frigate Shoals, Gracilaria millardetii (Table 2, Figure $2 G$ ) had been reported only from the Indian Ocean (Guiry and NicDhonncha 2005). The specimen collected at French Frigate Shoals is the first known central Pacific record and greatly increases the known range for this species.

Although this study is the first to report $H$. distorta in Hawai i, previous phylogenetic studies of the genus Halimeda used a specimen of this species from the island of Hawai $i$ for molecular analysis (specimen 97-059 in Kooistra et al. 1999 and Kooistra and Verbruggen 2005). Because of superficial similarities between $H$. distorta, $H$. copiosa Goreau \& Graham, and H. gracilis Harvey ex Agardh, past collections of $H$. distorta from the Hawaiian Islands may have been misidentified. Our specimens of $H$. distorta from French Frigate Shoals closely resemble the specimens of $H$. copiosa in Abbott and Huisman (2004), suggesting that critical examination of Hawaiian material from both species is necessary to solve possible taxonomic confusion. Halimeda gracilis is easily separated from $H$. distorta and H. copiosa on a microscopic level based on up to eight (rather than four) primary utricles arising from each secondary utricle and the clavate nature of utricular structure in $\mathrm{H}$. gracilis (Figure 2A-D).

The unidentified species of Laurencia (Figure $2 E$ ) was a small member of the turf community, and overall habit was too diminutive to analyze critically. However, cross sections revealed terete axis with projecting, radially elongated cortical cells, features not charac- teristic of any currently recognized Hawaiian species (McDermid 1988, Abbott 1999).

The relative distinctness of the Hawaiian macroalgal flora (French Frigate Shoals plus the main Hawaiian Islands) from that of most other Pacific islands is evident through multidimensional scaling analysis (Figure 3). Although only $34 \%$ of the species found in the main Hawaiian Islands (Abbott 1999, Abbott and Huisman 2004) are reported for French Frigate Shoals, $96 \%$ of the species found in French Frigate Shoals also occur in the main Hawaiian Islands (Table 1). When compared with other tropical Pacific islands (Table 3), the overall number of species encountered at French Frigate Shoals is low, probably because of its small geographic size and isolation. As discussed in McDermid et al. (2002), the biogeographic theory predicts relatively low biodiversity at small, remote islands. Ant Atoll is similar in size to French Frigate Shoals (McDermid et al. 2002), and both atoll systems contain almost the same number of species, although biodiversity differs. As suggested by McDermid et al. (2002), seasonality likely affects the algal flora of tropical systems, and additional species would likely be encountered at French Frigate Shoals during winter and spring months.

Past studies exploring biodiversity of Pacific island systems (McDermid et al. 2002) suggested that algal biodiversity of Micronesia exceeded that of French Polynesia. However, recent qualitative algal studies from Fiji (South and Skelton 2003) have greatly increased our understanding of South Pacific marine floras and indicate that sampling biases or a lack of recent collections may greatly skew biodiversity of a given area. Although our study relied on recent and thorough checklists of marine macroalgae to compare Pacific island floras, the Hawaiian Islands may appear distinct in the multi-

FIgURE 2. New species records for the Hawaiian Islands. A, Habit of Halimeda distorta (IA 27387). B, Utricles of Halimeda distorta (IA 27387), showing only two to four primary utricles (p) arising from each secondary utricle (s). $C$, Habit of Halimeda gracilis (PSV 20045). Although not new to the Hawaiian Island chain, past collections of Halimeda distorta have been confused with $\mathrm{H}$. gracilis, and this species is presented for comparison. $D$, Utricles of Halimeda gracilis (PSV 20045), showing up to eight primary utricles (p) arising from each secondary clavate utricle (s). E, Unidentified species of Laurencia (IA 27236) with radially elongate, projecting cortical cells (c). F, Siphons of Bryopsis indica (IA 27178). G, Habit of Gracilaria millardetii (IA 27556). 
TABLE 3

Total Number of Algal Species Reported for Pacific Islands or Archipelagoes

\begin{tabular}{|c|c|c|c|c|c|c|c|c|c|}
\hline & 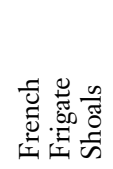 & 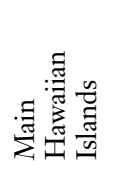 & 涪 & 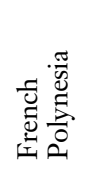 & 胥 & 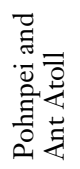 & స્ન & 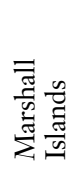 & $\frac{\vec{\Xi}}{\tilde{\sigma}}$ \\
\hline Greens & 42 & 100 & 147 & 102 & 99 & 70 & 83 & 114 & 92 \\
\hline Browns & 19 & 54 & 52 & 47 & 28 & 22 & 20 & 27 & 27 \\
\hline Reds & 118 & 336 & 286 & 165 & 114 & 130 & 97 & 145 & 92 \\
\hline Total & 179 & 490 & 485 & 314 & 241 & 222 & 200 & 286 & 211 \\
\hline
\end{tabular}

References: Setchell (1926), N'Yeurt et al. (1996), Payri and N'Yeurt (1997), Abbott (1999), Hodgson and McDermid (2000), Payri et al. (2000), Tsuda (2002a,b,c, 2003), Lobban and Tsuda (2003), McDermid et al. (2002), South and Skelton (2003), Abbott and Huis$\operatorname{man}(2004)$.

dimensional scaling ordination (Figure 3) simply because they have experienced a level of taxonomic scrutiny not yet afforded to other locations. The relationship of islands pre- sented will likely continue to change as our knowledge of Pacific island floras increases.

In conclusion, French Frigate Shoals represents a relatively unpolluted atoll system

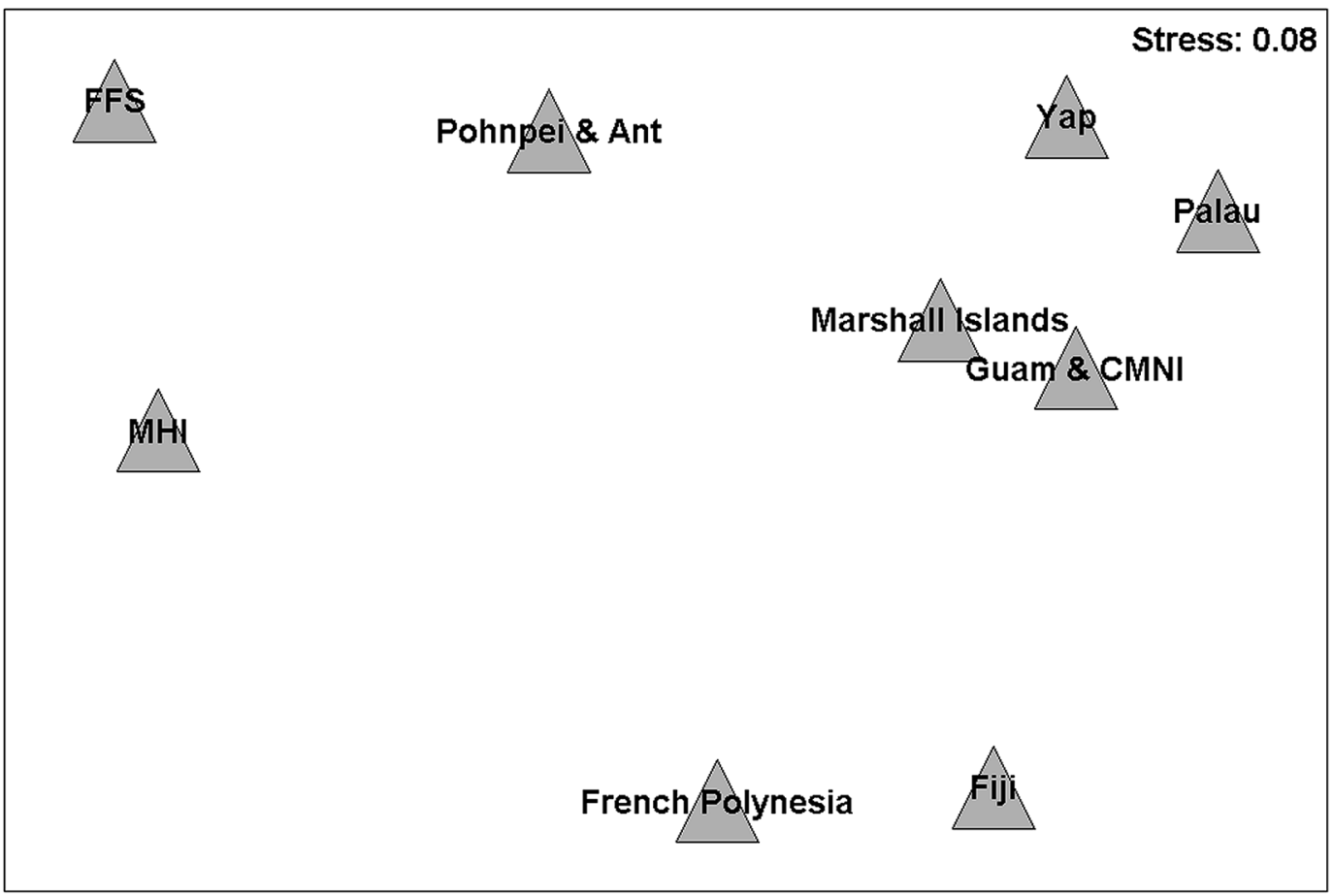

FIgUre 3. Multidimensional scaling plot comparing tropical Pacific islands based on presence/absence data of marine algal species. FFS, French Frigate Shoals; MHI, main Hawaiian Islands; CNMI, Commonwealth of the Northern Mariana Islands. 
with minimal anthropogenic influences, made evident by the lack of alien or invasive algae and a diverse algal flora. Establishing a thorough baseline of diversity in the marine flora of French Frigate Shoals is a necessary step in understanding the ecology of the atoll and how it relates to other islands. Comparisons of the flora of French Frigate Shoals with that of other Pacific regions established its similarity with that of the main Hawaiian Islands and uniqueness from that of most other Pacific islands. The subtropical climes and relative isolation of the Hawaiian Archipelago have thus allowed for a unique marine flora that warrants much additional study. As studies of other islands in the Northwestern Hawaiian Islands continue, so does the possibility of discovering additional algal species new to Hawai'i or new to science.

\section{ACKNOWLEDGMENTS}

We thank those involved with the field collections analyzed in this study: Karen Geisler, Jean Kenyon, Erica (Klohn) Muse, Karla McDermid, Ryan Okano, Linda Preskitt, and Brooke Stuercke. Special thanks to Isabella Abbott and Wiebe Kooistra for taxonomic expertise, Jim Maragos for use of his field notes, Ron Hoeke for map preparation, and the crews of the RV Rapture and NOAA Ship Townsend Cromwell for field support. Thanks also to Rusty Brainard, Mario Kalson, Jean Kenyon, and Jen Smith for critically reviewing the manuscript before submission. The Botany Department of the University of Hawai'i at Mānoa is acknowledged for their support of K.A.P.

\section{Literature Cited}

Abbott, I. A. 1989. Marine algae of the Northwest Hawaiian Islands. Pac. Sci. 43:223-233.

- 1999. Marine red algae of the Hawaiian Islands. Bishop Museum Press, Honolulu, Hawai'i.

Abbott, I. A., and J. M. Huisman. 2004. Marine green and brown algae of the $\mathrm{Ha}-$ waiian Islands. Bishop Museum Press, Honolulu, Hawai'i.
Agardh, J. G. 1885. Till algernes systematik. Nya bidrag. (Fjerde afdelningen.). Acta Univ. Lund. 21:1-120.

Balazs, G. H. 1979. Marine benthic algae collected from Kure Atoll, Maro Reef and Necker Bank, Northwestern Hawaiian Islands. 'Elepaio 39:110-111.

Børgesen, F. 1940. Some marine algae from Mauritius. I. Chlorophyceae. K. Dan. Vidensk. Selsk. Biol. Medd. 15:81.

- 1943. Some marine algae from Mauritius. III. Rhodophyceae. Part 2. Gelidiales, Cryptonemiales, Gigartinales. K. Dan. Vidensk. Selsk. Biol. Medd. 19:85.

Brostoff, W. N. 1984. Sporochnus dotyi sp. nov. (Sporochnales, Phaeophyta), a brown alga from Hawaii. Pac. Sci. 38:177-181.

Buggeln, R. G. 1965. A preliminary list of the algal flora of the Midway Islands. Atoll Res. Bull. 109:1-11.

Cheney, D. F. 1977. R\&C/P, a new and improved ratio for comparing seaweed floras. J. Phycol. 13 (Suppl.):12.

Chiappone, M., and K. M. Sullivan. 1997. Rapid assessment of reefs in the Florida Keys: Results from a synoptic survey. Proc. 8th Int. Coral Reef Symp. 2:1509-1514.

Chiappone, M., K. M. Sullivan, and R. Sluka. 1997. Status of reefs in the central Bahamas based on a large-scale survey. Proc. 8th Int. Coral Reef Symp. 1:345-350.

Chiappone, M., K. Sullivan-Sealey, G. Bustamante, and J. Tschirky. 2001. A rapid assessment of coral reef community structure and diversity patterns at naval station Guantánamo Bay, Cuba. Bull. Mar. Sci. 69:373-394.

Clarke, K. R., and R. M. Warwick. 2001. Change in marine communities: An approach to statistical analysis and interpretation 2nd ed. PRIMER-E, Plymouth.

Coppejans, E., F. Leliaert, and O. De Clerck. 2000. Annotated list of new records of marine macroalgae for Kenya and Tanzania, since Isaac's and Jaasund's publications. Biol. Jaarb. Dodonaea 67:31-93.

Coppejans, E., F. Leliaert, O. Dargent, and O. De Clerck. 2001. Marine green algae (Chlorophyta) from the north coast of Papua New Guinea. Cryptogam. Algol. 22:375-443. 
Costa, Jr., O. S., M. J. Attrill, A. G. Pedrin, and J. C. De-Paula. 2002. Spatial and seasonal distribution of seaweeds on coral reefs from southern Bahia, Brazil. Bot. Mar. 45:346-355.

Cribb, A. B. 1996. Seaweeds of Queensland: A naturalist's guide. The Queensland Naturalists' Club, Brisbane.

Diaz-Pulido, G., and J. M. Diaz. 1997. Algal assemblages in lagoonal reefs of Caribbean oceanic atolls. Proc. 8th Int. Coral Reef Symp. 1:827-832.

Diaz-Pulido, G., and J. Garzón-Ferreira. 2002. Seasonality in algal assemblages on upwelling-influenced coral reefs in the Colombian Caribbean. Bot. Mar. 45:284292.

Dodge, R. E., A. Logan, and A. Antonius. 1982. Quantitative reef assessment studies in Bermuda: A comparison of methods and preliminary results. Bull. Mar. Sci. 32:745760.

Friedlander, A. M., and E. E. DeMartini. 2002. Contrasts in density, size, and biomass of reef fishes between the Northwestern and the main Hawaiian Islands: The effects of fishing down apex predators. Mar. Ecol. Prog. Ser. 230:253-264.

Gepp, A., and E. S. Gepp. 1908. Marine algae (Chlorophyceae and Phaeophyceae) and marine phanerogams of the 'Sealark' Expedition, collected by J. Stanley Gardiner, M.A., F.R.S., F.L.S. Trans. Linn. Soc. Lond., series II 7:163-188.

Guiry, M. D., and E. NicDhonncha. 2005. AlgaeBase version 3.0. World-wide electronic publication, National University of Ireland, Galway. http://www.algaebase. org; searched on 16 April 2005.

Hillis-Colinvaux, L. W. 1968. New species of Halimeda: A taxonomic reappraisal. J. Phycol. 4:20-35.

Hodgson, L. M., and K. J. McDermid. 2000. Marine plants of Pohnpei and Ant Atoll: Chlorophyta, Phaeophyta, and Magnoliophyta. Micronesica 32:289-307.

Hollenberg, G. J. 1968. An account of the species of the red alga Herposiphonia occurring in the central and western tropical $\mathrm{Pa}$ cific Ocean. Pac. Sci. 22:536-559.
Joly, A. B. 1957. Contribuição ao conhecimento da flora ficológica marinha da Baía de Santos e Arredores. Bol. Fac. Filos. Cienc. Let. Univ. Sao Paulo, Ser. Bot. 14:3-199.

Kooistra, W. H. C. F., and H. Verbruggen. 2005. Genetic patterns in the calcified tropical seaweeds Halimeda opuntia, $H$. distorta, $H$. bederacea, and H. minima (Bryopsidales, Chlorophyta) provide insights in species boundaries and interoceanic dispersal. J. Phycol. 41:177-187.

Kooistra, W. H. C. F., M. Calderón, and L. W. Hillis. 1999. Development of the extant diversity in Halimeda is linked to vicariant events. Hydrobiologia 398/399:3945.

Kraft, G. T. 2000. Marine and estuarine benthic green algae (Chlorophyta) of Lord Howe Island, South-western Pacific. Aust. Syst. Bot. 13:509-648.

Liddell, W. D., and S. L. Ohlhorst. 1987. Patterns of reef community structure, North Jamaica. Bull. Mar. Sci. 40:311329.

Lobban, C. S., and R. T. Tsuda. 2003. Revised checklist of benthic marine macroalgae and seagrasses of Guam and $\mathrm{Mi}$ cronesia. Micronesica 35-36:54-99.

Maragos, J., and D. Gulko, eds. 2002. Coral reef ecosystems of the Northwestern Hawaiian Islands: Interim results emphasizing the 2000 surveys. U.S. Fish and Wildlife Service and the Hawai'i Department of Land and Natural Resources, Honolulu.

McDermid, K. J. 1988. Laurencia from the Hawaiian Islands: Key, annotated list, and distribution of the species. Pages 231-245 in I. A. Abbott, ed. Taxonomy of economic seaweeds. Vol. 2. California Sea Grant College Program, Report No. TCSGCP-018.

McDermid, K. J., L. M. Hodgson, and I. A. Abbott. 2002. Marine plants of Pohnpei and Ant Atoll: Rhodophyta, with biogeographic comparisons to other Pacific atolls and island groups. Micronesica 34:113140.

McField, M. D., P. Hallock, and W. C. Jaap. 2001. Multivariate analysis of reef commu- 
nity structure in the Belize barrier reef complex. Bull. Mar. Sci. 69:745-758.

Meinesz, A. 1999. Killer algae. The University of Chicago Press, Chicago.

Montagne, C., and P. M. A. Millardet. 1862. Botanique, cryptogamie, Algues. In L. Maillard, ed. Notes sur l'île de Réunion (Bourbon). Annexe O. Dentu, Paris.

Miller, J. E., R. K. Hoeke, T. B. Appelgate, P. J. Johnson, J. Smith, and S. Bevacqua. 2003. Bathymetric atlas of the Northwestern Hawaiian Islands (Draft, May). National Oceanic and Atmospheric Administration and Hawai'i Mapping Research Group. (Also available at http:// crei.nmfs.hawaii.edu/BathyAtlas/)

N'Yeurt, A. D. R., G. R. South, and D. W. Keats. 1996. A revised checklist of the benthic marine algae of the Fiji Islands, South Pacific (including the island of Rotuma). Micronesica 29:49-98.

Payri, C. E., and A. D. R. N'Yeurt. 1997. A revised checklist of Polynesian benthic marine algae. Aust. Syst. Bot. 10:867-910.

Payri, C., A. N'Yeurt, and J. Orempüller. 2000. Algae of French Polynesia (Algues de Polynésie Française). Edition Au Vent des îles, Papaeete, Tahiti.

Pham-Hoàng, H. 1969. Rong biên Viêtnam (Marine algae of South Vietnam). TrungTâm Học-Liệu, Saigon.

Phillips, J. A. 1997. Algae. Pages 223-240 in R. J. F. Henderson, ed. Queensland plants: Names and distribution. Queensland Herbarium, Department of Environment, Indooroopilly, Queensland.

- 2002. Algae. Pages 228-244 in R. J. F. Henderson, ed. Names and distribution of Queensland plants: Algae and lichens. Queensland Government Environmental Protection Agency, Brisbane.

Rogers, C. S., M. Gilnack, and H. C. Fitz. 1983. Monitoring of coral reefs with linear transects: A study of storm damage. J. Exp. Mar. Biol. Ecol. 66:285-300.

Sahoo, D., Nivedita, and Debasish. 2001. Seaweeds of Indian coast. A. P. H. Publishing, New Delhi.

Schils, T., and E. Coppejans. 2003. Spatial variation in subtidal plant communities around the Socotra Archipelago and their biogeographic affinities within the Indian Ocean. Mar. Ecol. Prog. Ser. 251:103114.

Setchell, W. A. 1926. Tahitian algae collected by W. A. Setchell, C. B. Setchell, and H. E. Parks. Univ. Calif. Publ. Bot. 12:61-142.

Silva, P. C., E. G. Meñez, and R. L. Moe. 1987. Catalog of the benthic marine algae of the Philippines. Smithson. Contrib. Mar. Sci. 27:iv-179.

Silva, P. C., P. W. Basson, and R. L. Moe. 1996. Catalogue of the benthic marine algae of the Indian Ocean. Univ. Calif. Publ. Bot. 79:1-1259.

South, G. R., and P. A. Skelton. 2003. Catalogue of the marine benthic macroalgae of the Fiji Islands, South Pacific. Aust. Syst. Bot. 16:699-758.

Teo, L. W., and Y. C. Wee. 1983. Seaweeds of Singapore. Singapore University Press, Singapore.

Tsuda, R. T. 1965. Marine algae from Laysan Island with additional notes on the vascular flora. Atoll Res. Bull. 110:1-22.

- 1966. Marine benthic algae from the Leeward Hawaiian group. Atoll Res. Bull. 115:1-13.

-2002a. Checklist of the marine benthic algae from the Palau Archipelago based on past references. Palau Int. Coral Reef Center Publ. 02-019.

. 2002b. Checklist and bibliography of the marine benthic algae from islands and atolls within Yap State, Federated States of Micronesia. University of Guam Marine Laboratory. Technical Report No. 105. - 2002c. Checklist and bibliography of the marine benthic algae from the Marshall Islands. University of Guam Marine Laboratory Technical Report No. 106.

- 2003. Checklist and bibliography of the marine benthic algae from the Mariana Islands (Guam and CNMI). University of Guam Marine Laboratory Technical Report No. 107.

Verheij, E., and W. F. Prud'homme van Reine. 1993. Seaweeds of the Spermonde Archipelago, SW Sulawesi, Indonesia. Blumea 37:385-510. 
Vroom, P. S., and I. A. Abbott. 2004a. Acrosymphyton brainardii sp. nov. (Gigartinales, Rhodophyta) from French Frigate Shoals, Northwestern Hawaiian Islands. Phycologia 43:68-74.

- 2004b. Scinaia huismanii sp. nov. (Nemaliales, Rhodophyta): An addition to the exploration of the marine algae of the Northwestern Hawaiian Islands. Phycologia 43:445-454.

Vroom, P. S., and C. M. Smith. 2001. The challenge of siphonous green algae. Am. Sci. 89:524-531.

2003. Reproductive features of Hawaiian Halimeda velasquezii (Bryopsidales, Chlorophyta), and an evolutionary assess- ment of reproductive characters in Halimeda. Cryptogam. Algol. 24:355-370.

Womersley, H. B. S., and A. Bailey. 1970. The marine algae of the Solomon Islands. Philos. Trans. R. Soc. Lond., B Biol. Sci. 259:257-352.

Yamada, U. 1941. (On the species of Halimeda from Micronesia.) Kagaku Nanyõ 4:108-121.

Yoshida, T. 1998. Marine algae of Japan. Uchida Rokakuho Publishing, Tokyo.

Yoshida, T., Y. Nakajima, and Y. Nakata. 1990. Check-list of marine algae of Japan (revised in 1990). Jap. J. Phycol. 38:269320.

Appendix

GPS Coordinates and Depths of Collection Sites

\begin{tabular}{|c|c|c|c|c|}
\hline Site No. & Date & Latitude & Longitude & Max. Depth (m) \\
\hline \multicolumn{5}{|c|}{ Townsend Cromwell: 1990 (1 site) } \\
\hline & $7 / 01 / 1990$ & $23^{\circ} 55^{\prime} \mathrm{N}$ & $166^{\circ} 20^{\prime} \mathrm{W}$ & \\
\hline \multicolumn{5}{|c|}{ Townsend Cromwell: 2000 (11 sites) } \\
\hline FFS-1 & $9 / 11 / 2000$ & $23^{\circ} 53.515^{\prime} \mathrm{N}$ & $166^{\circ} 17.685^{\prime} \mathrm{W}$ & 9.1 \\
\hline FFS-2 & $9 / 11 / 2000$ & $23^{\circ} 52.037^{\prime} \mathrm{N}$ & $166^{\circ} 18.283^{\prime} \mathrm{W}$ & 10.7 \\
\hline FFS-6 & $9 / 13 / 2000$ & $23^{\circ} 47.683^{\prime} \mathrm{N}$ & $166^{\circ} 04.974^{\prime} \mathrm{W}$ & 4.9 \\
\hline FFS-7 & $9 / 13 / 2000$ & $23^{\circ} 47.326^{\prime} \mathrm{N}$ & $166^{\circ} 13.198^{\prime} \mathrm{W}$ & 12.2 \\
\hline FFS-8 & $9 / 13 / 2000$ & $23^{\circ} 47.357^{\prime} \mathrm{N}$ & $166^{\circ} 13.588^{\prime} \mathrm{W}$ & 12.8 \\
\hline FFS-9 & $9 / 14 / 2000$ & $23^{\circ} 43.957^{\prime} \mathrm{N}$ & $166^{\circ} 10.375^{\prime} \mathrm{W}$ & 9.1 \\
\hline FFS-10 & $9 / 14 / 2000$ & $23^{\circ} 44.691^{\prime} \mathrm{N}$ & $166^{\circ} 10.363^{\prime} \mathrm{W}$ & 6.1 \\
\hline FFS-11 & $9 / 14 / 2000$ & $23^{\circ} 46.107^{\prime} \mathrm{N}$ & $166^{\circ} 15.689^{\prime} \mathrm{W}$ & 10.7 \\
\hline FFS-12 & $9 / 15 / 2000$ & $23^{\circ} 38.265^{\prime} \mathrm{N}$ & $166^{\circ} 10.768^{\prime} \mathrm{W}$ & 12.2 \\
\hline FFS-13 & $9 / 15 / 2000$ & $23^{\circ} 38.894^{\prime} \mathrm{N}$ & $166^{\circ} 09.311^{\prime} \mathrm{W}$ & 4.6 \\
\hline FFS-14 & $9 / 15 / 2000$ & $23^{\circ} 39.098^{\prime} \mathrm{N}$ & $166^{\circ} 10.411^{\prime} \mathrm{W}$ & 15.2 \\
\hline \multicolumn{5}{|c|}{ Rapture: 2000 (7 sites) } \\
\hline rFFS-2 & $9 / 23 / 2000$ & $23^{\circ} 38.531^{\prime} \mathrm{N}$ & $166^{\circ} 10.427^{\prime} \mathrm{W}$ & 6.1 \\
\hline rFFS-6 & $9 / 24 / 2000$ & $23^{\circ} 37.963^{\prime} \mathrm{N}$ & $166^{\circ} 07.465^{\prime} \mathrm{W}$ & 7.9 \\
\hline rFFS-8 & $9 / 24 / 2000$ & $23^{\circ} 42.937^{\prime} \mathrm{N}$ & $166^{\circ} 03.452^{\prime} \mathrm{W}$ & 8.5 \\
\hline rFFS-10 & $9 / 24 / 2000$ & $23^{\circ} 49.845^{\prime} \mathrm{N}$ & $166^{\circ} 06.620^{\prime} \mathrm{W}$ & 15.2 \\
\hline rFFS-22 & $9 / 26 / 2000$ & $23^{\circ} 47.322^{\prime} \mathrm{N}$ & $166^{\circ} 10.886^{\prime} \mathrm{W}$ & 5.8 \\
\hline rFFS-24 & $9 / 27 / 2000$ & $23^{\circ} 39.166^{\prime} \mathrm{N}$ & $166^{\circ} 13.225^{\prime} \mathrm{W}$ & 12.2 \\
\hline rFFS-26 & $9 / 27 / 2000$ & $23^{\circ} 42.556^{\prime} \mathrm{N}$ & $166^{\circ} 12.148^{\prime} \mathrm{W}$ & 17.4 \\
\hline \multicolumn{5}{|c|}{ Townsend Cromwell: 2001 (10 sites) } \\
\hline FFS-H6 & $9 / 13 / 2001$ & $23^{\circ} 52.810^{\prime} \mathrm{N}$ & $166^{\circ} 16.392^{\prime} \mathrm{W}$ & 11.6 \\
\hline FFS-H7 & $9 / 13 / 2001$ & $23^{\circ} 51.169^{\prime} \mathrm{N}$ & $166^{\circ} 17.871^{\prime} \mathrm{W}$ & 7.9 \\
\hline FFS-H8 & $9 / 13 / 2001$ & $23^{\circ} 51.292^{\prime} \mathrm{N}$ & $166^{\circ} 16.149^{\prime} \mathrm{W}$ & 6.7 \\
\hline FFS-H5d & $9 / 14 / 2001$ & $23^{\circ} 51.747^{\prime} \mathrm{N}$ & $166^{\circ} 13.787^{\prime} \mathrm{W}$ & 5.8 \\
\hline FFS-H5e & $9 / 14 / 2001$ & $23^{\circ} 51.673^{\prime} \mathrm{N}$ & $166^{\circ} 13.689^{\prime} \mathrm{W}$ & 6.4 \\
\hline FFS-H23 & $9 / 14 / 2001$ & $23^{\circ} 51.241^{\prime} \mathrm{N}$ & $166^{\circ} 13.354^{\prime} \mathrm{W}$ & 6.7 \\
\hline FFS-15 & $9 / 14 / 2001$ & $23^{\circ} 51.789^{\prime} \mathrm{N}$ & $166^{\circ} 12.687^{\prime} \mathrm{W}$ & 5.8 \\
\hline FFS-17 & $9 / 15 / 2001$ & $23^{\circ} 52.372^{\prime} \mathrm{N}$ & $166^{\circ} 12.979^{\prime} \mathrm{W}$ & 5.8 \\
\hline FFS-18 & $9 / 15 / 2001$ & $23^{\circ} 43.600^{\prime} \mathrm{N}$ & $166^{\circ} 09.900^{\prime} \mathrm{W}$ & 7.0 \\
\hline FFS-19 & $9 / 15 / 2001$ & $23^{\circ} 44.664^{\prime} \mathrm{N}$ & $\begin{array}{ll}166^{\circ} & 10.324^{\prime} \mathrm{W}\end{array}$ & 7.3 \\
\hline
\end{tabular}


Appendix (continued)

\begin{tabular}{|c|c|c|c|c|}
\hline Site No. & Date & Latitude & Longitude & Max. Depth (m) \\
\hline \multicolumn{5}{|c|}{ Townsend Cromwell: 2002 (12 sites) } \\
\hline FFS-20 & $9 / 11 / 2002$ & $23^{\circ} 51.667^{\prime} \mathrm{N}$ & $166^{\circ} 19.368^{\prime} \mathrm{W}$ & 12.5 \\
\hline FFS-21 & $9 / 11 / 2002$ & $23^{\circ} 50.806^{\prime} \mathrm{N}$ & $166^{\circ} 19.601^{\prime} \mathrm{W}$ & 11.3 \\
\hline FFS-22 & $9 / 11 / 2002$ & $23^{\circ} 51.956^{\prime} \mathrm{N}$ & $166^{\circ} 15.323^{\prime} \mathrm{W}$ & 3.0 \\
\hline FFS-24 & $9 / 12 / 2002$ & $23^{\circ} 46.071^{\prime} \mathrm{N}$ & $166^{\circ} 03.721^{\prime} \mathrm{W}$ & 12.2 \\
\hline FFS-25 & $9 / 12 / 2002$ & $23^{\circ} 42.249^{\prime} \mathrm{N}$ & $166^{\circ} 03.648^{\prime} \mathrm{W}$ & 12.5 \\
\hline FFS-26 & $9 / 12 / 2002$ & $23^{\circ} 43.774^{\prime} \mathrm{N}$ & $166^{\circ} 03.134^{\prime} \mathrm{W}$ & 13.1 \\
\hline FFS-27 & $9 / 13 / 2002$ & $23^{\circ} 47.745^{\prime} \mathrm{N}$ & $166^{\circ} 04.281^{\prime} \mathrm{W}$ & 13.7 \\
\hline FFS-28 & $9 / 13 / 2002$ & $23^{\circ} 48.855^{\prime} \mathrm{N}$ & $166^{\circ} 05.407^{\prime} \mathrm{W}$ & 12.5 \\
\hline FFS-29 & 9/13/2002 & $23^{\circ} 50.613^{\prime} \mathrm{N}$ & $166^{\circ} 08.204^{\prime} \mathrm{W}$ & 14.0 \\
\hline FFS-30 & $10 / 04 / 2002$ & $23^{\circ} 50.984^{\prime} \mathrm{N}$ & $166^{\circ} 17.811^{\prime} \mathrm{W}$ & 7.9 \\
\hline FFS-31 & $10 / 04 / 2002$ & $23^{\circ} 51.925^{\prime} \mathrm{N}$ & $166^{\circ} 14.396^{\prime} \mathrm{W}$ & 6.4 \\
\hline FFS-32 & $10 / 04 / 2002$ & $23^{\circ} 48.421^{\prime} \mathrm{N}$ & $166^{\circ} 13.874^{\prime} \mathrm{W}$ & 8.8 \\
\hline \multicolumn{5}{|c|}{ Rapture: 2002 (16 sites) } \\
\hline rFFS-28 & $9 / 11 / 2002$ & $23^{\circ} 49.586^{\prime} \mathrm{N}$ & $166^{\circ} 14.440^{\prime} \mathrm{W}$ & 7.6 \\
\hline rFFS-29 & $9 / 11 / 2002$ & $23^{\circ} 40.740^{\prime} \mathrm{N}$ & $166^{\circ} 08.527^{\prime} \mathrm{W}$ & 3.4 \\
\hline rFFS-30 & $9 / 11 / 2002$ & $23^{\circ} 51.511^{\prime} \mathrm{N}$ & $166^{\circ} 12.347^{\prime} \mathrm{W}$ & 1.8 \\
\hline rFFS-31 & $9 / 11 / 2002$ & $23^{\circ} 44.612^{\prime} \mathrm{N}$ & $166^{\circ} 10.280^{\prime} \mathrm{W}$ & 7.6 \\
\hline rFFS-32 & $9 / 12 / 2002$ & $23^{\circ} 44.237^{\prime} \mathrm{N}$ & $166^{\circ} 03.170^{\prime} \mathrm{W}$ & 15.5 \\
\hline rFFS-33 & $9 / 12 / 2002$ & $23^{\circ} 40.808^{\prime} \mathrm{N}$ & $166^{\circ} 04.128^{\prime} \mathrm{W}$ & 14.0 \\
\hline rFFS-34 & $9 / 12 / 2002$ & $23^{\circ} 39.803^{\prime} \mathrm{N}$ & $166^{\circ} 04.794^{\prime} \mathrm{W}$ & 12.2 \\
\hline rFFS-36 & $9 / 12 / 2002$ & $23^{\circ} 38.707^{\prime} \mathrm{N}$ & $166^{\circ} 10.550^{\prime} \mathrm{W}$ & 12.2 \\
\hline rFFS-38 & $9 / 13 / 2002$ & $23^{\circ} 38.149^{\prime} \mathrm{N}$ & $166^{\circ} 11.138^{\prime} W$ & 24.1 \\
\hline rFFS-39 & $9 / 13 / 2002$ & $23^{\circ} 51.596^{\prime} \mathrm{N}$ & $166^{\circ} 10.350^{\prime} \mathrm{W}$ & 15.2 \\
\hline rFFS-40 & $9 / 13 / 2002$ & $23^{\circ} 51.373^{\prime} \mathrm{N}$ & $166^{\circ} 09.766^{\prime} \mathrm{W}$ & 16.8 \\
\hline rFFS-41 & $9 / 13 / 2002$ & $23^{\circ} 51.958^{\prime} \mathrm{N}$ & $166^{\circ} 12.080^{\prime} \mathrm{W}$ & 16.8 \\
\hline rFFS-42 & 9/13/2002 & $23^{\circ} 51.714^{\prime} \mathrm{N}$ & $166^{\circ} 11.250^{\prime} \mathrm{W}$ & 11.9 \\
\hline rFFS-44 & $10 / 04 / 2002$ & $23^{\circ} 41.448^{\prime} \mathrm{N}$ & $166^{\circ} 16.135^{\prime} \mathrm{W}$ & 19.5 \\
\hline rFFS-45 & $10 / 04 / 2002$ & $23^{\circ} 51.492^{\prime} \mathrm{N}$ & $166^{\circ} 11.410^{\prime} \mathrm{W}$ & 1.8 \\
\hline rFFS-46 & $10 / 04 / 2002$ & $23^{\circ} 46.168^{\prime} \mathrm{N}$ & $166^{\circ} 15.680^{\prime} \mathrm{W}$ & 6.1 \\
\hline
\end{tabular}

Note: The NOAA ship Townsend Cromwell was used for cruises led by the NOAA Fisheries Coral Reef Ecosystem Division. The RV Rapture was used for the multiagency Northwestern Hawaiian Islands Reef Assessment and Monitoring Program (NOWRAMP). 
